\title{
Resistência violenta aos governos injustos
}

\author{
Goffredo Telles Junior \\ (Cateđrático de Introđução à Ciência do Direito)
}

\begin{abstract}
Sumário: 1. Introdução. - 2. 0 chamado "direito de resistência à opressão" e o direito positivo. - 3. Constituição das sociedades humanas. - 4. Sociedade política e govêrno legítimo. - 5. O govêrno injusto. - 6. Os governos contra os quais é admissível a resistência violenta. - 7. Requisitos da resistência violenta. -8 . Conclusão.
\end{abstract}

\section{Introdução}

Em quê casos será admissivel a resistência violenta aos govêrnos injustos?

Resposta a esta pergunta me tem sido solicitada numerosas vêzes, por grupos diversos de estudantes, de várias Faculdades de São Paulo. Bem sei que os moços desejam (ou desejavam) uma justificação doutrinária para certas atitudes que haviam tomado, ou queriam tomar, dentro de determinadas circunstâncias históricas de nosso país.

Após criteriosa meditação, resolvi dar, agora, num trabalho sistemático, a minha solução ao momentoso problema. Mas, antes de mais nada, faço questão de frizar que êste trabalho não visa, expressa ou ocultamente, condenar, justificar ou explicar qualquer fato real da política brasileira. Tenho verificado que, em assuntos como o que vou versar, a simples menção a fatos realmente acontecidos obumbra muitas vêzes as consciências. Aquilo 
que é mera especulação científica passa a ser interpretado como crítica dos acontecimentos e, mesmo, como expressão de uma atitude partidária. $\mathrm{E}$, então, as palavras recebem um sentido que originàriamente não tinham, as afirmações são deturpadas, e as mais altas teses são rebaixadas à categoria de explicações forjadas de acôrdo com algum dos interêsses em luta. Fáceis e comuns são as facciosas interpretações em matéria política, principalmente numa hora de paixões exacerbadas, como é a fase que ora atravessamos.

Fiquem, pois, fora destas páginas, os ódios, os fanatismos e os interêsses, que degradam e dividem os homens. Diligenciemos para que a serenidade impregne nosso pensamento. E, subindo para a querida Pátria das Idéias, deixemo-nos arrastar por um só amor, que é o nosso amor pela verdade.

\section{O chamado "direito de resistência à opressão" e o direito positivo}

A faculdade de resistir à opressão dos governos tem sido exercida muitas vêzes no correr da história. Eis um fato incontestável. $\mathrm{O}$ que se,discute é a qualidade jurídica dessa faculdade. Será ela um direito?

A filosofia política do Século XVIII, desejando prestigiá-la, incluiu-a no ról dos direitos naturais do homem. $\mathrm{E}$ os revolucionários americanos e franceses de 1776 e 1789 a consagraram como um dos direitos originários, inatos, inalteráveis e imprescritíveis do sêr humano.

A Declaração de Independência dos Estados Unidos (1776) sustenta: "Os governos são instituídos entre os homens para garantir êsses direitos (direito à vida, liberdade e procura da felicidade), e seu justo poder emana do consentimento dos governados. Tôdas as vêzes que uma forma de governo se torna destrutiva dêsse fim, o 
povo tem o direito de mudá-la ou de abolí-la, e de estabelecer um novo governo, fundando-o sôbre os princípios e organizando-o pela forma que the parecerem os mais próprios para lhe dar a segurança e a felicidade. ( . .) Quando uma longa série de abusos e de usurpações, tendendo invariàvelmente para o mesmo fim, marca o desígnio de submeter os homens ao despotismo absoluto, é de seu direito, é de seu dever rejeitar um tal govêrno, e prover, com novas garantias, sua segurança futura".

Esses princípios estão consignados em várias constituições dos Estados Unidos da América. A de Massachusetts (1780) os reproduz quase como se acham na citada Declaração. A da Virgínia (1902) os acolhe nos seguintes têrmos: "se um governo fôsse jamais reconhecido inadequado ou contrário a êsses fins, uma maioria da coletividade teria um direito incontestável, inalienável e imprescritível de reformá-lo, mudá-lo, abolí-lo, pela maneira que julgar mais útil ao bem público". E a de Maryland (1867) acrescenta: "A doutrina da não resistência ao poder arbitrário e à opressão é absurda, servil e destruidora do bem e da felicidade da humanidade".

O mais célebre documento em que se acha proclamado o direito à resistência é, sem dúvida, a Declaração dos Direitos do Homem e do Cidadão, adotado pela Assembléia Nacional Constituinte da França, em 26 de agôsto de 1789, promulgada a 3 de novembro do mesmo ano, e publicada no alto da Constituição Francesa de 1781. O artigo segundo dessa memorável Declaração está redigido nos seguintes têrmos: "O fim de tôda associação política é a conservação dos direitos naturais e imprescritiveis do homem. Ésses direitos são a liberdade, a propriedade, a segurança e a resistência à opressão".

Em maio de 1793, a Convenção Nacional Francesa adotou nova Declaração de Direitos, cujo artigo primeiro proclama os direitos do homem em sociedade, entre os quais figura o de resistência à opressão. Não satisfeita, a 
Convenção, em junho do mesmo ano, votou ainda outra Declaração, em que o referido direito acha-se consignado nos seguintes têrmos: "A lei deve proteger a liberdade pública e individual contra a opressão dos que governam (. .) Quando o governo viola os direitos do povo, a insurreição é para o povo e para cada porção do povo, o mais sagrado dos direitos e o mais indispensável dos deveres". Esta última Declaração serviu de cabeçalho ao Ato Constitucional de 24 de junho de 1793.

Tais foram as mais conhecidas consagraçõ̃es legislativas do chamado direito de resistência à opressão.

Forçoso é reconhecer que êsse direito, tão decantado pelos revolucionários franceses e americanos do Século XVIII, tão lapidarmente inscrito em documentos históricos dessa época, não conta, atualmente, com fundamentos bem seguros no direito positivo dos povos. Comparando-se as legislações modernas com os textos que acabam de ser citados, verifica-se imediatamente o progressivo desprestígio em que vai caindo o direito de resistência à opressão dos governos.

Demonstrativa dêste declínio, é a evolução do direito francês. Já na Declaração dos Direitos e dos Deveres do Homem e do Cidadão, colocada no alto da Constituição da República Francesa de 1795, não há mais menção ao referido direito, que foi deliberadamente substituído pelos "deveres" a que se referem os seguintes artigos: "5. Ninguém é bom cidadão, se não é francamente e religiosamente observador das leis. - 6. Aquêle que viola abertamente as leis se declara em estado de guerra com a sociedade". Nas Disposições Gerais dessa Constituição, encontram-se dois expressivos artigos, a saber: " 365 . Todo ajuntamento armado é um atentado à Constituição; deve ser dissolvido imediatamente pela fôrça. - 366. Todo ajuntamento não armado deve ser igualmente dissolvido, primeiro por via de comando verbal, e, si fôr necessário, por meio da fôrça armada". A Constituição de 1799, que 
também não menciona o direito de resistência à opressão, estabelece no seu artigo 92: "No caso de revolta a mão armada, ou de perturbações que ameaçam a segurança do Estado, a lei pode suspender, nos logares e durante o tempo que ela determinar, o império da Constituição". Isto significa que a lei podia suspender os direitos do homem e do cidadão. No preâmbulo da Carta Constitucional de 1814, há uma observação curiosa: "quando a violência arranca quaisquer concessões da fraqueza do Govêrno, a liberdade pública não está em menos perigo do que o próprio trono". "Como se vê, a resistência à opressão não é mais mencionada nas leis. A ela não se referem o Ato Adicional às Constituições do Império de 1815, a Declaração dos Direitos dos Franceses e dos Princípios Fundamentais de sua Constituição do mesmo ano, a Carta Constitucional de 1830 e a Constituição da República Francesa de 1848. A Constituição de 1852 e a Constituição do Império de 1870, sem referência especial a cada um dos "direitos naturais e imprescritiveis do homem", reconhecem, confirmam e garantem, englobadamente, "os grandes princípios proclamados em 1879, e que são a base do direito público francês". Mas a Constituição de 1875, limitando-se a organizar os poderes públicos, não faz nenhuma alusão a tais direitos. Quando foi questão de se saber se essa omissão da Constituição importava inexis̄tência dos referidos direitos, o Presidente do Conselho deu, sôbre o assunto, em 1883, o seguinte parecer: "não há constituição tácita. . não há direitos constitucionais em reticencias. A existencia desses direitos é fundamental, mas não é constitucional no sentido legal da palavra."A atual Constituição de República Francesa, elaborada depois da dominação nazista e publicada em 28 de outubro de 1946, não menciona expressamente, como seria de se esperar, o direito de resistência à opressão; limita-se a declarar, no seu preâmbulo que o povo francês "reafirma solenemente os direitos e as liberdades do homem e do cidadão consagrados pela Declaração dos Direitos de 1789". 
A que conclusão nos leva o cotejo dêsses textos? Considerando-se que a França foi o país por excelência dos Direitos do Homem, muitas vêzes reafirmados, um a um, em Declarações sucessivas, e a pátria de filósofos, políticos e legisladores que tanto timbraram em proclamar o direito de resistência à opressão, parece inegável que, a partir de 1795 , as constituições francesas revelam um claro recuo no terreno das garantias ao direito de resistência, ou, ao menos, um menoscabo crescente por tal questão.

Aliás, êsse desinteresse ou alheiamento não é fenômeno exclusivo da França. Dentro do direito positivo moderno, é patente o desprestígio do direito de resistência. A êle não se referem as constituições de após guerra. E enquanto vai sendo cada vez mais relegado ao esquecimento, as legislações aprimoram, progressivamente, as medidas de repressão aos movimentos insurrecionais.

No Brasil, por exemplo, onde não há qualquer referência legislativa ao direito de resistência, a Constituição, em seu artigo 141, § 5. ${ }^{\circ}$, prescreve: "Não será tolerada propaganda de guerra, de processos violentos para subverter a ordem política e social, ou de preconceitos de raça ou de classe". E o Decreto-lei n. 431, de 18 de maio de 1938 , definiu os crimes contra a estrutura e a segurança do Estado e contra a ordem social, cominando-lhes penas diversas, inclusive a pena de morte para os casos mais graves.

A tendência moderna é, em verdade, a de reprimir severamente as conspirações e os atentados, levados a efeito contra os governos instituídos. Qual será o motivo de uma tal mudança de atitude?

Creio poder afirmar, sem receio de engano, que tal mudança foi determinada pela evolução das próprias circunstâncias históricas. A faculdade de resistir à opressão dos governos será sempre considerada um direito, pelos vencedores de grandes movimentos revolucionários. Arrebatados pelo entusiasmo da vitória, os revolucionários 
terão sempre a disposição de promover a direito - e muitas vêzes a direito sagrado — todos os impulsos que os os levaram a se erguer de armas na mão. Com a intenção de conferir legitimidade cada vez mais incontestável aos movimentos insurrecionais (que, entretanto, causam derramamento de sangue, desordem pública, paralização das atividades normais do povo), seus promotores costumam proclamar que agiram no exercício de um direito natural. Leiam-se, por exemplo, as expressivas palavras com que o relator Romme apresentou à Convenção Nacional Francesa, a Declaração dos Direitos de 1793: "A insurreição é um direito sagrado, imprescritível e superior à lei, e êsse direito em seu exercício não conhece outro regulador afora as virtudes mesmas dos oprimidos e seu devotamento generoso e sublime à conservação da liberdade pública. É pela insurreição que rompemos nossos ferros em 1789; é ainda por meio dela que a tirania foi derribada em 1792. Em reconhecimento e para dar uma lição às nações e às gerações futuras, uma estátua deveria ser erguida à insurreição e colocada como uma sentinela perto da estátua da liberdade, afim de lembrar contìnuamente ao povo os seus direitos, e aos ambiciosos o castigo que aguarda os usurpadores".

Nas épocas normais, porém, desprestigia-se inevitàvelmente, aos olhos do Estado, o chamado direito de resistência à opressão. Os governos, que não são produtos da revolução, mas constituídos pacìficamente, de acôrdo com as leis vigentes, não compreendem e não admitem a hipótese de serem substituídos por meio da revolução. E os outros têm a tendência irreprimível de acreditar que a última revolução legítima, no presente e no futuro da nação, foi a que lhes deu o poder. Em consequência, as leis passam a silenciar sôbre o referido,direito.

Mas o que me cumpre investigar é sôbre se o direito de resistência à opressão tem ou não existência real, seja qual for, nesta matéria, a orientação flutuante dos governos. 
Quando mencionamos o direito de resistência à opressão, queremos nos referir, evidentemente, a um direito subjetivo; mais precisamente, a um direito subjetivo público, uma vez que seu objéto seria o de limitar o poder do governo.

Ora, a observação fria e desapaixonada da realidade jurídica, sem qualquer preconceito dogmático viciando nossa investigação, leva-nos à noção de que todo direito subjetivo é uma faculdade cujo exercício não pode ser impedido sem a violação de uma norma jurídica. Os conceitos mais amplos do direito subjetivo, como o da teoria dos "direitos naturais subjetivos", perdem em compreensão o que ganham em extensão. Conferir o nome de direito a faculdades humanas cujo exercício não seja assegurado por lei, é extender o conceito do direito a esferas que estão além da esfera do direito. Esta extensão, que não oferece qualquer vantagem científica, representa incontestável prejuízo para a precisão da terminologia jurídica.

A verdade é que não há direito subjetivo ou faculdade jurídica sem correlativa norma jurídica. As faculdades do homem, cujo exercício pode ser impedido sem violação de norma jurídica (ou, em outros termos, as faculdades do homem, cujo exercício não for garantido por norma jurídica), não são faculdades jurídicas, não são direitos subjetivos. Serão faculdades naturais, mas não faculdades jurídicas, no sentido técnico desta expressão. É o que acontece, por exemplo, com a faculdade de difamar, de furtar, de falsificar moeda, de matar, de incitar ao crime, que são, incontestàvelmente, faculdades do homem, mas que não são faculdades jurídicas, precisamente porque seu exercício pode ser impedido sem violação de uma norma de direito.

Acrescentemos que todo direito subjetivo compreende, além da faculdade cujo exercício não pode ser impedido sem violação de correspondente norma jurídica, o poder de exigir respeito a essa mesma faculdade. Pois, a norma jurídica, sôbre que se funda o direito subjetivo, é sempre 
norma atributiva (sob pena de não ser jurídica): ela atribuí a quem seria lesado pela sua violação o poder de exigir seu cumprimento. Como não vivemos mais no regime da vingança privada e da justiça feita com as próprias mãos dos interessados, êsse poder se socorre da fôrça do govêrno, que é a entidade incumbida de fazer cumprir as normas jurídicas. Em consequência, é inadmissível a existência de direitos subjetivos contra a fôrça do governo. Terão os homens, certamente, a faculdade de lutar contra a fôrça do governo, mas essa faculdade: não é uma faculdade jurídica, não é um direito subjetivo.

Não se aleguem, em oposição a esta tése, o direito de ação judiciária contra o Estado, os direitos ao mandado. de segurança e ao habeas-corpus. Em nenhum dêstes: casos, existe direito subjetivo contra a fôrça do govêrno. Lembremo-nos de que a lei é expressão da vontade do govêrno. E êste é o motivo pelo qual o govêrno não lança sua fôrça contra aquêle que, em juízo, pleiteia de acôrdo com as leis. Vencido em ação judiciária, não usará o govêrno. de sua fôrça para ilidir o julgado. Voluntàriamente, sujeitar-se-à à decisão judiciária. Não é possível afirmar-se, portanto, que os referidos direitos são direitos subjetivos. contra a vontade e a fôrça do govêrno.

Em resumo: não há direito subjetivo sem lei que o garanta, e não há direito subjetivo contra a vontade e a fôrça do govêrno.

Isto posto, fica patente que a faculdade de resistir à opressão dos governos não é, em rigor, um direito subjètivo. Tal faculdade, glorificada muitas vêzes em períodos revolucionários, desaparece das legislações nas épocas de paz. Em regra, nenhuma lei a garante. Pelo contrário: as leis a consideram crime e a reprimem, fixando penas, às vêzes gravíssimas, para aquêles que ousarem exercê-la. Mas mesmo quando alguma lei a consagra como direito, impossível será, sob pena de incongruência, acreditar numa tal consagração. Pois nenhum govêrno reconhecerá 
que exerce opressão. Em consequência, nenhum govêrno dará o apôio de sua fôrça à resistência que se fizer a suas ordens. A faculdade de resistir à opressão terá que se apoiar em outras fôrças. $\mathrm{E}$ isto é suficiente para deixar demonstrado que essa faculdade não é um direito, no sentido técnico da palavra.

Rigorosamente dentro da esfera do direito, só o governo é juiz do que é jurídico e do que é injurídico. Outras esferas éticas existem, sem dúvida, que escapam da competência dos governos, como as da moral e da religião. Mas é função precípua do govêrno declarar o direito, porque é de sua responsabilidade conduzir o grupo social. Poderá o direito ser julgado iníquo pela consciência de todos; mas só é direito a norma a que o govêrno confere essa qualidade.

Prova insofismável do que se acaba de afirmar é o fato, tantas vêzes verificado na história humana, de que as revoluções sỏ se legitimam quando triunfam. $O$ novo govêrno sempre tem motivos de sobejo para proclamar a opressão exercida pelo govêrno deposto; por conseguinte, será levado a colocar tôda a sua fôrça a serviço dos revolucionários. Mas se a revolução fracassa, ela é imediatamente considerada um crime, mesmo nos países onde a faculdade de resistir à opressão é tida como jurídica. Nada mais seria preciso dizer para deixar provado que da lei não depende, em absoluto, a legitimidade ou a ilegitimidade do fato da resistência.

Razão plena tem Léon Duguit quando escreve: " $\mathbf{E}$ claro que a questão da legitimidade de uma insurreição não poderá formular-se jamais em têrmos de direito positivo perante um tribunal. Se a insurreição triunfa, o govêrno que dêle sair certamente não mandará perseguir, por atentado à segurança do Estado ou por conspiraçăo, aquêles a que deve o poder; e si a insurreição fracassa, não haverá um tribunal que ouse declarar que não houve atentado contra a segurança do Estado". 
Mas, aqui, uma grave questão se coloca. Uma vez demonstrado que resistir à opressão não é o exercício de um direito, pergunta-se: tal exercício constituirá sempre uma prática reprovável?

A resposta a esta pergunta só pode ser negativa. Pelo fato de não ser o exercício de um direito, não fica demonstrado que uma ação é reprovável. Não são reprovaveis, mas ações muitas vêzes heróicas, certas violências que se cometem para pôr fim a iniquidades praticadas à sombra do direito.

A faculdade de resistir à opressão dos governos não é um direito. Ł́ uma faculdade natural. Mas os governos não foram feitos para oprimir o homem, e sim para auxiliá-lo na sua dura caminhada em direção a seu destino. Contra os governos opressores, os homens às vêzes exercem sua faculdade de legítima defesa, sem se preocuparem com o aspecto jurídico de sua atitude. O problema da resistência à opressão não é um problema de direito positivo. A resistência é um fato, cuja legitimidade (não legalidade) é questão meta-jurídica, porque depende diretamente, não da lei, mas da consonância dêsse fato com os autênticos interêsses da vida humana.

Em quê casos existe tal consonância? Esta é a questão que vamos analisar.

\section{Constituição das sociedades humanas}

A descoberta dos casos em que é admissivel a resistência violenta aos governos injustos exige, como preliminar, uma clara conceituação do govêrno injusto. E esta conceituação só pode ser inferida dos princípios que informam o poder público. Eis porque devo iniciar minha dissertação com o enunciado de dados triviais, mas básicos, sôbre a constituição das sociedades humanas, de que o poder público é um dos elementos imprescindiveis. 
Unas e homogêneas foram, segundo parece, as sociedades primitivas. Depois, teriam evoluído, em conformidade com o processo pelo qual evoluem todos os organismos do mundo físico e do mundo moral. Quê processo será êste? Podemos chamá-lo processo de integração. Em quê consiste? Consiste na aplicação do princípio em virtude do qual a evolução dos corpos se verifica pela diferenciação progressiva de suas partes e de suas funções e pela progressiva coordenação dessas partes e dessas funções.

Em suas orígens, a sociedade se reduzia à família ou à horda: era um só todo, pequeno e simples. À medida que foi evoluindo, o grupo inicial tornou-se pletórico e a cisão se impôs. Em consequência, multiplicaram-se os grupos, formando, em conjunto, uma sociedade cada vez mais ampla. Pouco a pouco, vai desaparecendo a primitiva homogeneidade, e, consequentemente, aumentando a complexidade social. Quanto mais evoluida foi se tornando a sociedade, mais numerosas, mais variadas e mais caracterizadas iam sendo as suas partes. Formaram-se grupos de tôdas as naturezas: grupos biológicos, grupos pedagógicos, grupos econômicos e profissionais, grupos políticos, grupos religiosos, etc. E cada grupo, cada parte do conjunto, foi tomando o encargo de uma função específica, a desempenhar dentro do todo. Esta progressiva caracterização das partes, e esta distribuição de tarefas, funções ou encargos entre tais partes constituem, exatamente, o que se denomina movimento de diferenciação.

Mas evolução não é apenas diferenciação. A diferenciação das partes e das funções acarreta, como é claro, a interdependência dessas mesmas partes e funções. Nas sociedades complexas, cada indivíduo, cada grupo, executando a sua tarefa especial, necessita, para viver, da colaboração dos outros indivíduos, dos outros grupos, que se entregaram a outras tarefas especiais. Onde houver complexidade, nada basta a si mesmo. Uns necessitam dos outros. E, então, impõe-se a solidariedade social. O fato 
de solidarizar as partes e conjugar as funções constitui, exatamente, o que se denomina movimento de coordenação. Eis porque a sociedade se integra não sòmente pela progressiva diferenciação de suas partes componentes, mas também pela progressiva coordenação dessas mesmas partes.

A sociedade humana é, portanto, uma unidade fleita de variedade. Para a exata compreensão da estrutura social, esta é uma observação de capital importância. Os. homens vivem dentro dos mais heterogêneos grupos sociais, mas todos êstes grupos compõem um só todo. $\mathrm{O}$ desconhecimento desta realidade fundamental impede uma visão verdadeira das condições em que se desenrola a existência humana.

O homem vive na sociedade e em sociedaủes. Êle não se contenta com viver numa só sociedade. Para incrementar o bem comum, para multiplicar suas possibilidades de ação, os homens formam grupos sociais dentro da sociedade. Êsses grupos, como expliquei, são inúmeros e de naturezas diversas: são famílias, escolas, universidades, associações culturais, associações esportivas e recreativas, associações profissionais e de classe (como sindicatos, corporações, guildas), sociedades agrícolas, sociedades mercantís, sociedades industriais, instituições, fundações, confrarias, ordens (como as ordens religiosas), grêmios, partidos, municípios, igrejas, etc. Hoje, a sociedade se apresenta a nossos olhos como um imenso organismo, composto de um sem número de órgãos diferentes.

Mas o que desejo salientar, desde logo é que tais órgãos ou grupos sociais, apezar de tôdas as suas diferenças, apresentam três notas comuns, que merecem nossa especial atenção.

A primeira nota comum é a seguinte: o grupo social se forma, sempre, para a consecução intencional de um certo bem, que é a causa final da associação. Com isto, o homem mais uma vez revela sua natureza racional, pois, 
como dizia Santo Thomaz, "êle age pelo intelecto que opera, manifestamente, em vista do fim". Num determinado momento, alguém enuncia uma idéia de um bem a atingir, e concita seus semelhantes a se agruparem para realizála. A idéia se propaga e, se fôr persuasiva, solidariza os homens que gostariam de vê-la realizada, mas que não a podem realizar a não ser em grupo.

Tal idéia é, pois, o objeto provocador da associação; chega a ser sua causa principal, porque, na formação do grupo, ela é a causa que move tôdas as outras causas, e constitui a fôrça organizadora da vida social. A idéia atua, congrega, impulsiona, dirige, provoca a organização de meios para a realização do fim que ela representa. Ela tem a vocação da positividade: não lhe basta ser idéia, anceia ser realidade. Como pode uma idéia ter tamanha influência? Pela consciência de sua necessidade ou de sua conveniência, em cada um dos componentes, ou dos futuros componentes do grupo. Essa consciência gera obediência. Obediência a quê? Aos imperativos que conduzem para aquêle bem, em torno de cuja idéia os homens se agruparam.

Este é o fundamento do poder legítimo nas sociedades humanas. Que é, na sua essência, o poder legítimo? Nada mais do que isto: a fôrça exercida pela idéia de um bem a realizar, sôbre consciências solidarizadas pelo império dessa mesma idéia, e capaz de impor aos membros do grupo as atitudes que ela determina.

A segunda nota comum a todos os grupos sociais decorre diretamente da primeira: è a comunhão humana em razão da idéia de um bem a realizar. Num grupo social, os homens não se acham simplesmente juxtapostos, uns ao lado dos outros, como os paus num monte de lenha. Acham-se, isto sim, associados, de maneira a se completarem reciprocamente. Num grupo social, não há uma simples agregação material de homens, mas uma comuntdade organizada. Essa comunhão é a condição necessária 
à remoção de obstáculos que impedem os homens isolados de atingir certos bens. Ela é, portanto, um meio. Sendo meio, deve ordenar-se para o fim em razão do qual se constituiu. Em consequência, a ordem da comunhão humana em cada grupo social depende das repercussões da idéia a realizar, nas consciências dos componentes do grupo. Por êsse motivo, cada grupo social tem a sua própria ordenação interna.

A terceira nota comum de todos os grupos sociais é a seguinte: cada um dêles tem o seu govêrno. Em que consiste o govêrno de um grupo social? Govêrno é o órgão do poder. Poder, como já sabemos, é a fôrça exercida pela idéia de um bem a realizar, sôbre consciências solidarizadas pelo império dessa mesma idéia. $O$ poder se acha, portanto, na idéia a realizar e, por extensão, nas normas necessárias a essa realização. O govêrno não é o poder, mas a encarnação do poder num homem ou numa equipe de homens. $\mathrm{O}$ poder não se confunde com os homens que o encarnam. Estes homens é que constituem o governo. Sob a figura do chefe que comanda, existe, como diria George Burdeau, a idéia que legitima o comando. $O$ poder está na idéia, o govêrno está no chefe.

Desde logo se verifica que o govêrno seria um órgão inútil se os homens fôssem seres socialmente perfeitos, isto é, se tivessem sempre uma clara consciência do bem comum e se deixassem guiar por tal consciência. Neste caso, a simples ídéia a realizar, agindo diretamente sôbre os espíritos, seria a melhor autoridade para o govêrno dos homens.

Sucede, entretanto, que essa perfeição não existe. Três fatôres principais se somam para dificultar a verdadeira comunhão humana: a indiferença ou desinterêsse de um grande número de associados pela sorte da coletividade, o desconhecimento ou falso conhecimento do bem comum por parte de outros, e, finalmente, o natural egoismo humano, que inverte, frequentemente, a escala dos 
bens, colocando interêsses particulares secundários acima dos superiores interêsses coletivos. Daí a necessidade de um govêrno, que é um órgão vivo, com inteligência, vontade e fôrça, para suprir a indiferença e o desinterêsse de muitos, para traçar o caminho a ser percorrido por todos, e para vencer as vontades rebeldes dos que deixaram a luz do bem comum ser ofuscada, em suas consciências, pelo brilho de seus interêsses pessoais.

Santo Thomaz observa: "Enquanto a natureza é suficiente para conservar a unidade do corpo humano, a unidade do corpo social depende daquêle que é seu chefe".

\section{Sociedade política e govêrno legítimo}

Como expliquei, todo grupo social - família, escola, sindicato, sociedade mercantil, cidade, província, nação, igreja, ou qualquer outro - se constitui para a realização de uma determinada idéia, ou seja, para a consecução intencional de um certo bem, que é a causa final da associação. Ora, em certos grupos, o bem a atingir é um bem exclusivo do grupo, enquanto que, em outros, o bem visado não é exclusivo do grupo, porque, de sua consecução, depende a consecução dos bens exclusivos dos grupos da primeira espécie. Realmente, alguns grupos se caracterizam por seu altruismo, uma vez que se organizam para o único fim de condicionarem a realização de idéias alheias. Estes grupos se chamam sociedades políticas.

A sociedade política, como todos os grupos sociais, se constitui para a realização de uma determinada idéia. Quê idéia será esta? A resposta se encontra na definição da sociedade política: grupo social cuja idéia a realizar consiste em se constituir condiçâo para que as entidades, que ela encerra, melhor se aproximem de seus respectivos fins.

Nas sociedades não políticas, a idéia a realizar, impondo-se a diversas consciências, determina e acarreta a 
comunhão humana; nas sociedades políticas, a idéia da comunhão humana é, ela mesma, a idéia a realizar.

Nas sociedades não políticas, a comunhão humana é o meio pelo qual o grupo procura atingir os seus fins; nas sociedades politicas, a própria comunhão humana é o fim almejado.

Uma sociedade mercantil não é uma socicdade política; nela, a comunhão humana é o meio empregado para a consecução dos objetivos comerciais próprios do grupo. Uma corporação de sindicatos operários e patronais é uma sociedade politica, pois que búsca realizar a comunhão entre operários e patrões. São sociedades políticas, por exemplo, a tribu, a cidade, o município, o cantão, o condado, a província, a nação.

Desde logo se patenteia a dificuldade da missão atribuída aos que fôrem incumbidos do governo destas sociedades. Poucos são os homens realmente capazes de encarnar o poder político. Nem poderia ser de outro modo: poucos são os artistas, poucos os filósofos, poucos os cientistas; por quê motivo os políticos seriam muitos? Os julgamentos e as representações individuais não têm, todos, o mesmo valor: a apreciação justa, o julgamento imparcial, a decisão firme são privilégios raros. Político, na acepção autêntica do têrmo, é sòmente quem, tendo vencido suas inclinações egoisticas, aceitou, como princípio de comportamento, o princípio que lhe forr ditado pelo bem da comunidade; político é sòmente quem recebeu o dom de distinguir, na dissonante polifonia social, o apêlo harmonico dos autênticos interêsses coletivos, e a energia de se guiar por êle. Todo govêrno legítimo há de ter, portanto, um certo caráter aristocrático; só uma cega ou interesseira demagogia sustentaria o contrário.

O governante com poder legítimo é sempre o instrumento de uma idéia que "achou nêle a ocasião de se expandir". A autoridade do govêrno se funda, portanto 
na sua fidelidade à idéia de que ẻ o executor. Sem êsse fundamento espiritual, o govêrno se degrada; não é mais do que uma fôrça bruta de dominação: em vez de órgão do poder, é órgão da violência. Neste caso, qualquer falha da chefia, qualquer esmorecimento, fraqueza ou descuido do chefe, acarreta a desagregação do organismo social, cuja unidade era mantida por coação. A história universal demonstra que a fôrça material jamais conseguiu sustentar, por muito tempo, os governos contra os quais se ergue o poder das idéias constitucionais da sociedade. Impossível, em verdade, exercer "a coação a jacto contínuo".

A fidelidade do govêrno à sua idéia política se comprova pelo consentimento que lhe é dado por aquêles que lhe estão submetidos. Não se pense, que êste consentimento exige manifestações explícitas. O normal é o consentimento tácito, a aprovação silenciosa, a não resistência, e mesmo a tolerância. $O$ govêrno que realiza a idéia para que foi constituído não provoca protestos que lhe sejam fatais e recebe a aprovação, geralmente não expressa, dos que desejam essa realização. E a coação exercida contra alguns se legitima pela anuência da maioria.

Expresso ou tácito, o consentimento dos governados é condição da verdadeira autoridade política. Santo Thomaz observa que "o povo, por si mesmo ou por seus representantes legítimos, consente que tal medida editada seja considerada como justa". Não é a autoridade que gera a obediência, mas, antes, a obediência (resultante da convicção de que ela é necessária) é que condiciona a autoridade. Já se tem assinalado que o govêrno precisa do apôio da opinião pública, não só para ser legítimo como também para ser poderoso.

Isto não significa, entretanto, que a autoridade política venha do consentimento popular. $O$ poder legitimo nunca será demais repetí-lo - é a fôrça exercida por uma 
idéia sôbre as consciências. O poder político não é senão essa mesma fôrça espiritual. A autoridade dos governos lhes advem de sua fidelidade à idéia que lhes cumpre realizar e de cuja fôrça os governos se constituem os órgãos atualizadores. Como as idéias se originam nas consciências individuais, o consentimento dessas consciências, dado ao govêrno, é uma demonstração de que os interessados na realização das mesmas, reconhecem a fidelidade do govêrno. $O$ consentimento não é mais do que êsse reconhecimento.

Importantíssimo, entretanto, um tal reconhecimento. É êle que confere ao govêrno, não a sua autoridade (que tem outra fonte), mas a sua autonomia, sem a qual seria impossível a procura e o estabelecimento dos meios capazes de levar a sociedade a seus fins.

Uma vez reconhecida a fidelidade do govêrno aos objetivos da sociedade, adquire êle liberdade para a escolha das vias conducentes a êsses objetivos. Um govêrno sem autonomia, isto é, um govêrno dirigido pelos governados, executa um papel passivo e, em consequência, não cumpre a sua missão de guia. Não é próprio de um govêrno ser dirigido pelos governađos.

A idéia de ordem social não se apresenta a todos os espíritos de um modo uniforme: aos indiferentes, essa idéia não interessa; para os ignorantes, ela é um mistério; para os maus, um obstáculo a ser superado; e para os outros, embora represente um bem ambicionado, tal idéia não tem sempre contornos precisos, nem surge nos espíritos com linhas nítidas. Muitas vêzes, ela não é uma idéia, mas uma infinidade de idéias, e, o que é mais grave, uma infinidade de idéias em movimento, à procura de um modêlo, que nunca se afirma e sempre se renova. Muitas vêzes, também, longe de ser um todo perfeito e acabado, é uma idéia fragmentada em elementos esparsos pelas consciências individuais, porque poucos serão os compo- 
nentes da sociedade política que estejam em condições de ter uma visão global da ordem.

Dia por dia, alteram-se as condições e as circunstâncias sociais; os imprevistos e os imponderáveis transformam, a cada momento, as situações; e a exuberância da vida cria, sem cessar, novidades imprevistas. Todo êsse movimento se verifica, não há dúvida, em determinados sentidos, mas o sentido do movimento social exige, para ser percebido e compreendido, um alto mirante, do qual o olhar do observador abrace o conjunto global dos fenômenos sociais. Não serão, certamente, os indivíduos e as entidades particulares, entregues a setores especializados de atividades, que irão indicar os rumos da evolução coletiva.

Lento e acidentado é o percurso das idéias no espírito dos homens, e o melhor juízo normativo poderá levar séculos para se transformar em norma costumeira. Impossível, pois, deixar ao critério dos particulares a declaração das normas substanciais ou de garantia, que são as normas componentes da ordem jurídica. Daí a necessidade de um govêrno dotado de autonomia.

A função do governo é encarnar as mais profundas aspirações do grupo e suprir as imperfeições da compreensão coletiva. Compete-lhe dar solução às questões sôbre as quais não existe, ainda, opinião geral manifestada; compete-lhe ser a voz daqueles juízos normativos necessários, que se obstinam em permanecer, por tempo indeterminado, no mundo oculto das representações subjetivas; compete-lhe fazer nascer a norma concebida no seio da sociedade; compete-lhe dar precisão aos anseios difusos da coletividade e sistematizar os ideais dispersos; compete-Ihe definir com clareza os fins sociais e, prevendo o de que a sociedade vai precisar, instruir os espíritos para suscitar o desabrochamento dos juízos que o futuro vai exigir; compete-lhe discernir o momento em que as normas vigorantes começam a caducar e as condições a reclamar nova regulamentação, e tomar medidas prudentes 
afim de evitar que o eterno conflito entre a ordem estabelecida e os imperativos da equidade degenerem em desordem; compete-lhe compelir a sociedade a ser, na realidade, o que ela confusamente quer ser; compete-lhe, enfim, descobrir e proclamar um plano de ação, dando forma e consistência à ordem constitucional.

\section{O govêrno injusto}

Um govêrno só é legítimo se fôr, realmente, órgão do poder, isto é, se estiver a serviço da idéia para cuja realização o grupo se constituiu. Um govêrno que se insurja contra essa idéia, ou a olvidar, terá perdido o senso de sua missão e se transformará numa violência contra a sociedade. Êsse governo não será a encarnação do poder, mas a encarnação da fôrça. Imporá, è certo, uma ordem social, mas esta ordem é obtida por compressão; é uma ordem mecânica e portanto precária, porque não contará com a adesão das consciências. Dentro do grupo social, deflagrar-se-á uma luta surda entre duas fôrças concorrentes: a fôrça governamental e o poder das idéias. E a experiência demonstra que as ordens artificiais, mantidas pela fôrça, são incapazes de conter, por muito tempo, o ímpeto vital das idéias constitucionais do grupo.

Aliás, os limites impostos à autoridade dos governos decorrem da própria natureza das cousas. Um governo não é uma fantasia. Os homens não se submetem a uma autoridade objetiva por um mero capricho de sujeição. A existência de um govêrno tira a sua razão de ser da necessidade de realizar uma determinada idéia e, portanto, da necessidade de ser implantada uma ordem apropriada a essa realização. $O$ fim a atingir fixa os limites do poder dos governos, desde o primeiro momento em que, por um ato constitucional, o grupo é organizado. E a isto, provàvelmente, que Hauriou denominou "auto-limitação objetiva própriamente constitucional". Burdeau, também, exprimindo a mesma idéia, sustenta que o govêrno não pode 
manumitir-se da idéia de que procede, a não ser arruinando o seu fundamento.

0 fundamento da autoridade de um govêrno reside nà convicção de que uma idéia deve ser realizada e de que o govêrno é o instrumento dessa realização. A referida autoridade será legítima, portanto, se houver adequação da atividade do govêrno aos seus fins; mas se o govêrno, proclamando sua alforria, se desviar dos fins para que foi criado, aquela mesma convicção, que era a prova de sua legitimidade, volta-se contra êle, para destruí-lo.

Pode suceder que um chefe, divorciado da idéia constucional da sociedade, conquiste o govêrno e se imponha pelas armas; pode suceder, tambèm, que um govêrno, legìtimamente constituído, seja arrastado por apetites inconfessáveis e, em consequência, manumita-se da idéia de que procede. Tais governos promulgarão ordens jurídicas em desacôrdo com as aspirações profundas da sociedade e manterão o equilíbrio social por meio da fôrça e da corrupção. Nestes casos, o poder é substituído pelo arbítrio, a fidelidade pela violência. O problema que então se coloca cifra-se na seguinte pergunta: será legítima a resistência violenta a tais governos, por parte dos governados?

Máxima prudência é exigida na orientação dos povos nessa emergência, porquanto tanto pode a capitulação diante do despotismo levar à escravidão e ao extermínio, como pode a resistência intempestiva contra a ordem estabelecida levar à anarquia e à degradação. A resposta à pergunta formulada deve, portanto, ser deduzida, cuidadosamente, dos princípios já expostos.

Os govêrnos contra os quais é admissivel a resistência violenta.

Um govêrno pode ser injusto de duas maneiras diferentes: por sua origem ou por seu funcionamento. 
É injusto por sua origem, o govêrno que se instala pela fôrça ou pela fraude, sem atenção para as idéias constitucionais do grupo. Tal governo è injusto, porque não é fruto de uma exigência natural do poder legítimo. Já expliquei que o poder legítimo é a fôrça de uma idéia de ordem, que os elementos componentes de um grupo social querem ver realizada. E o governo legítimo é o órgão dêsse poder, instituído para realizar a referida idéia. Qualquer govêrno, portanto, que não fôr organizado pelo próprio grupo, com o objetivo predeterminado de conduzílo a seus fins, e que, por golpe de fôrça ou manobra fraudulenta, se instala e passa a dominar, constitui um atentado vibrado contra a sociedade.

Necessário é notar, porém, que o vício original de um govêrno não o desacredita definitivamente. Pode um govêrno, injusto por sua origem, tornar-se justo por seu funcionamento, e redimir-se. Um govêrno imposto pelas armas ou pela astúcia pode tornar-se, por sua ação, órgão do poder legítimo. Se êsse govêrno receber o consentimento da maior parte daqueles que lhe estão submetidos, comprovando-se assim a sua fidelidade às idéias fundamentais do grupo social, não será mais possível taxá-lo de injusto. Em consequência, ilegítima será a resistência violenta a um tal govêrno.

Mas pode um govêrno, regularmente instituído, tornarse injusto por seu funcionamento. Esta hipótese se verifica em dois casos diferentes: no de êrro e no de abuso.

Assim como qualquer homem está sujeito a engano na apreciação de um fato, pode um homem de govêrno se equivocar, quanto aos verdadeiros imperativos do bem comum. Embora colocado num mirante privilegiado de observação social, e embora dedicado ao serviço dos ideais coletivos, iludir-se-á, uma vez ou outra, sôbre o autêntico interêsse geral, e cairá em êrro. Êste será, é certo, um êrro involuntário. Mas, apezar de involuntário, terá a aparência de uma arbitrariedade. Óra, tôda arbitrarie- 
dade dos governos ocasiona uma reação social. Deante de uma tal reação, o govêrno, que agiu de bôa fé, verificará que cometeu um êrro, e logo tomará as providências necessárias para neutralizá-lo. Intempestiva, pois, seria a resistência violenta a um govêrno que, agindo de bôa fé, torna-se injusto por êrro.

Incomparàvelmente mais grave, é o caso do govêrno injusto por abuso de função. Êste abuso na condução dos negócios públicos pode ter duas causas: ou a ambição depravada dos governantes, ou sua total desambição.

$\mathrm{Na}$ hipótese da ambição depravada dos governantes, os homens de govêrno são movidos pela influência sinistra de interêsses súbalternos. A idéia para cuja realização o govêrno foi criado, é conscientemente substituida por objetivos cuja consecução só beneficia os próprios governantes e seus amigos. E, então, a luz orientadora do bem comum é ofuscada pelo brilho tentador de bens particulares.

$\mathrm{Na}$ hipótese da total desambição dos governantes, o govêrno perde a noção de seus fïns. A idéia, da qual o governo deveria ser o instrumento, não é substituída por nenhuma outra idéia determinada ou definida: ela é simplesmente olvidada. Em consequência, o govêrno deixa de cumprir a sua missão de guia. Como barco sem vela e sem leme, deixa-se arrastar ao sabor de tôdas as correntezas.

Nessas duas hipóteses, o govêrno, sendo fator, ativo ou passivo, de subversão social, não é órgão do poder, não é pròpriamente govêrno, mas desgoverno. Seus mandamentos não são pròpriamente normas, não são imperativos do bem comum. Não conduzem: perdem, transviam. Não são mandamentos, mas desmandos.

Êsses dois governos acham-se afetados de um dos mais graves males políticos: o mal de não quererem se rege- 
nerar. Um germem nefasto, que parece irremovível, corrompe e destrói suas fibras morais. Ambos são injustos, e ambos sem esperança de redenção. Isto os torna intoleráveis. Em consequência, contra ambos se admite a resistência violenta.

\section{Requisitos da resistência violenta}

Admite-se a resistência violenta contra êsses dois tipos de govêrno injusto. Mas que espécie de resistência? Será admissivel uma resistência violenta que tenha objetivos tão nefastos como os que norteiam o governo que se quer derrubar? Ou que não tenha nenhum objetivo, senão o de depor o govêrno instituído?

Salta aos olhos que a aceitação da resistência violenta depende não sòmente da existência dos referidos governos injustos, mas também de certos requisitos ou qualidades da própria resistência. As condições extrínsecas que justificam a resistência violenta são os fatos ou circunstâncias sociais contra os quais ela se levanta. Mas quais serão suas condições intrínsecas?

Antes de tudo, é preciso não esquecer que, na sociedade política, ao lado da fôrça prepotente de um govêrno arbitrário, continuará vicejando, nas consciências, o poder das idéias constitucionais do grupo. É evidente que a resistência violenta contra uma ordem imposta pela fôrça só se torna legítima, quando a convicção de que as referidas idéias devem ser realizadas, se fizer dominante na opinião pública, e quando a resistência é feita em nome dessas idéias. Sem isto, qualquer resistência estará viciada pelo mesmo mal contra que ela se levantou. Não será legítima, pois, a resistência violenta levada a efeito em nome de idéias que não sejam as da generalidade do povo. 
Mas a simples legitimidade da resistência violenta não é suficiente para justificá-la; é preciso, ainda, que ela seja necessária. Não se admite, em verdade, o emprêgo de meios ilegais para a transformação da ordem, a não ser quando não fôr possível atingir o mesmo fim, por meios Iegais.

Mas não é só: embora legítìma e necessária, a resistência violenta sòmente estará justificada se fôr útil, isto é, se fôr realmente apta para restabelecer a ordem justa, pois, no caso contrário, haverá grande perigo de ser ela a causa de agravação dos males que afligem a sociedade. A agitação sorrateira, os levantes imaturos, os golpes ineficientes, praticados com o intuito de incomodar os governantes, sem esperança de alterar a ordem estabelecida, não podem ser considerados como resistência justa.

Finalmente, não se justifica, também, a resistência violenta que não fôr proporcional aos males que ela combate. Se a resistência violenta causar maiores transtornos e maiores escândalos do que os causados pelo govêrno a que se opõe, melhor será não fazê-la. Montaigne observa: " $O$ bem não sucede necessàriamente ao mal. Outro mal pode suceder-lhe, e êste peior".

Em suma, a resistência violenta só é admissível nos raros casos em que, sendo legítima, ela é necessária, útil e proporcional.

\section{Conclusão}

Para concluir, resumirei, em poucas palavras, tôda a argumentação desenvolvida.

Demonstrei, inicialmente, que o chamado "direito" de resistência à opressão dos governos não é um direito. Todo direito subjetivo se funda em lei, e seu exercício é assegurado pela fôrça do govêrno. A teoria dos "direitos 
subjetivos naturais" confere ao têrmo direito, sem vantagem de qualquer espécie e com incontestável prejuízo para a precisão da terminologia cientifica, uma extensão injustificada. Ora, o chamado "direito de resistência" não se funda em lei, mesmo quando a lei o reconhece, e não é jamais garantido pela fôrça do govêrno. Logo, a faculdade de resistir à opressão não é faculdade jurídica, não é direito subjetivo, no sentido técnico desta expressão. É, sim, uma faculdade natural do homem. E a resistência, considerada em si mesma, é um fato, cuja legitimidade (não legalidade) depende de sua consonância com os autênticos interêsses da vida humana. O problema da resistência à opressão não é um problema de direito positivo.

Em seguida, procurei determinar os casos em que o fato da resistência atende aos autênticos interêsses da vida humana. Verificou-se que existem condições de duas ordens para que haja consonância entre êsse fato e êstes interêsses. Em primeiro lugar, condições extrínsecas, que são as circunstâncias sociais cujos malefícios tornam admissível a resistência violenta. Em segundo lugar, condições intrinsecas da própria resistência, isto é, as qualidades ou requisitos que devem ornar a insurreição, para que possa ser considerada justa.

Quanto às condições extrínsecas, foi preciso descobrir, preliminarmente, os tipos de govêrno contra os quais é admissível a resistência violenta. Isto exigiu uma análise da sociedade, afim de se firmar o conceito de govêrno injusto. Esste conceito foi inferido dos princípios que informam o poder público. Verificou-se que o poder legítimo, num grupo social, é o império de uma idéia de ordem, sôbre as consciências daqueles que aceitaram essa idéia; e que o govêrno é o órgão de tal poder, isto é, o órgão que encarna e dinamiza a idéia de ordem social, para cuja realização o grupo existe. Em consequência, govêrno injusto é aquele que, insurgindo-se contra essa idéia 
ou olvidando-a, perde o senso de sua missão e se transforma em violência contra a sociedade.

Mas nem contra todos os governos injustos se admite a resistência violenta. Há governos injustos que se redimem, como foi explicado. Contra êstes, inoportuna seria a resistência violenta. E então concluí que essa resistência é admissível nos casos em que os governos se acham afetados de um mal sem cura, qual seja o de não quererem se regenerar. $\mathrm{E}$ apontei as duas hipóteses em que êsse mal se manifesta: não autoriza esperança de regeneração os governos levados por ambição depravada e os governos que se deixam levar por absoluta falta de ambição.

Uma vez indicadas as condições extrínsecas e sociais, que tornam admissivel o fato da resistência, restava indicar as condições intrínsecas da própria resistência. E, sobre este ponto, cheguei à seguinte conclusão: a resistência justa há de ser legítima, necessúria, útil e proporcional, conferindo-se a cada um dos adjetivos mencionados o sentido que lhes foi atribuido.

Assim, penso haver dado resposta, no puro campo da doutrina, à pergunta que motivou estas considerações.

São Paulo, 7 de junho de 1955. 